\title{
The Suitability of the GCC for Monetary Union
}

\author{
Michael Thorpe \\ College of Graduate Studies \\ University of Wollongong in Dubai \\ PO Box 20183, Dubai, UAE \\ Tel: 97-1-43672456 E-mail: michaelthorpe@ uowdubai.ac.ae
}

\begin{abstract}
The member states of the Gulf Cooperation Council (GCC) have proposed the establishment of a monetary union in 2010. While this has the potential to generate significant benefits for the group and individual member states in the context of wider economic integration, it also removes some flexibility in the macro-economic management of national economies. It is important, therefore, that alternative adjustment mechanisms are in place and effective in the face of asymmetric shocks to the union. This paper looks at the theoretical and empirical literature and identifies the potential benefits and costs associated with a monetary union. It highlights the criteria used to asses to what extent any particular union would be beneficial and sustainable longer term. The GCC is reviewed with reference to this literature and some observations made as to the likelihood of a successful union and what steps could be undertaken to facilitate this.
\end{abstract}

Keywords: Gulf Cooperation Council (GCC), Monetary union, Economic integration

\section{Introduction}

The member states of the Cooperation Council for the Arab States of the Gulf (GCC) are planning to establish a monetary union in 2010 as part of a wider agenda of economic integration across the group. While this has the potential to realise considerable benefits, it also means that the use of both the exchange rate mechanism and monetary policy as policy instruments will be lost to members. A number of pre-conditions or criteria can be identified to provide a guide as to how likely it is that the proposed union would be successful and what steps are required by member states to ensure benefits are maximised.

The paper is structured as follows. The next section provides a brief overview of the GCC economies in the context of later discussion on the characteristics favouring a sustainable union. This is followed by a discussion of the economic theory underpinning monetary union. The benefits and costs associated with a monetary union are then discussed with reference to this literature, followed by a section identifying pre-conditions. The proposed union is then assessed with reference to these criteria and current economic conditions.

\section{Background to the GCC}

The GCC was created in 1981 with one of its objectives being greater economic integration. The six member states, Bahrain, Kuwait, Oman, Qatar, the Kingdom of Saudi Arabia and the United Arab Emirates (UAE), established a free trade zone in 1983 and in 2001 a decision was made to establish full monetary union with the adoption of a single currency, by the end of January 2010. (Note 1) As a lead-up to the monetary union members officially pegged their currencies to the USD in 2002 and moved to form a customs union in 2005, (Fasano and Iqbal, 2002). (Note 2) Convergence criteria for a number of economic indicators were also agreed to at the end of 2005 as part of this process. Further, a common market was formally agreed to at the end of 2007, which once practically implemented will allow for free movement of labour and capital between the member states under similar policy arrangements.

The proposed currency union should be seen in the context of the wider reform agenda and restructuring occurring within the GCC as it looks to more closely integrate and re-position itself in the global economy. Members are looking to diversify their economies away from dependence on oil and gas exports and increase the non-oil share of GDP in their economies. As well as providing a less volatile base for export income, it is driven also by the need to generate employment in the face of a rapid population growth (Fasano and Iqbal, 2002; Woertz, 2007).

With a combined GDP of USD 725 billion (2006 figures), 45 per cent of the world's oil reserves and a population of 36 million, the proposed union would constitute the biggest currency area outside the Eurozone (Note 3). Although average income puts the GCC in the high-income group by World Bank reckoning, income distribution is uneven across the members. 


\section{The Economies of the GCC Member States}

Despite some evident differences, the members currently exhibit a marked degree of similarity in terms of economic structure (Sturm and Siegfried, 2005). They are relatively open economies and although (energy) resource endowments differ greatly across the region, they are to large degree dependent on oil and gas. (Hebous, 2006) (Note 4). The GCC as a group accounts for just over 42 per cent of global oil reserves and 23 per cent of natural gas reserves (Note 5). The share of oil and gas in export revenues (currently at an average of around 75 per cent for the GCC) is reflected in the sector's importance in both total output and government revenues (Tables 1 and 2).

Despite the strong growth in recent years, the member states face a number of challenges including a need to promote growth in non-oil sectors to create employment opportunities for a growing (and generally young) population (Tables 3 and 4). The work-force in the GCC is growing at 4 per cent annually, with one-third of the population under 15. The capital intensive petroleum industry is not a significant employment creator, while the traditional route for nationals, the civil service, is a limited option longer term. The pressures do vary across the region in respect of current and future energy reserves, population growth, unemployment rates and per capita income levels (Table 5) (Note 6). Bahrain has limited energy resources, while Qatar and Oman have dwindling oil reserves.

There is a growing push for privatisation, labour market reform and greater economic diversification, all of which are inter-related (Sturm and Siegfried, 2005; Darrat and Al Shamsi, 2005; Fasal and Iqbal, 2002). A broader export and output base and reduced reliance on oil revenues will help to insulate economies from terms of trade shocks and provide sustainable longer-term growth and employment opportunities. This is evident in the expansion of banking services, manufacturing and tourism in several countries. In view of the changes being pursued, it is likely that the economic structures of the member states will increasingly diverge in the future.

In terms of intra-regional trade, integration of member states is currently quite limited; it has remained around 5 per cent of total trade for many years. Although this rises to around one-third when only non-oil trade is considered, it varies markedly for different member states (Hebous, 2006; Sturm and Siegfried, 2005). GCC export markets are concentrated in Asia, while the European Union (EU) is the main source of imports. Investment links within the GCC have also been limited to date. Over 1990-2002, only 2 per cent of investment outflows was intra-regional, with substantial financial assets held outside the region. There is evidence that this pattern is changing as more funds are being directed internally.

The pegged exchange rates and openness to capital flows have effectively resulted in alignment of monetary policies (with US interest rates-see below). Inflation has, however, diverged across the members due to domestic supply constraints as well as the effects of the recent USD devaluation against major currencies. Fiscal positions, and hence current debt levels, have also varied across the GCC. These developments have put strains on the group's existing currency arrangements and have raised some doubts as to the likelihood of the 2010 timetable for the union(Note 7).

\section{Exchange Rates and Monetary Policy}

The objective in selecting an exchange rate regime should be to encourage efficient resource allocation and provide effective protection from foreign and domestic shocks for the local economy (Yehoue, 2007). In choosing to link its currency with one or more currencies, a country can adopt an exchange rate peg, a currency area or a monetary union (Tavlas, 1993). A peg involves fixed rates between partners, with no fluctuations, while a currency area goes further and conducts a common monetary policy, no exchange controls within the area and full economic and financial market integration. A monetary union reflects a deeper integration, with a single currency and a common central bank or coordinating body. As a result, there is a community approach to exchange rate management in dealing with the rest of the world.

In the literature an optimum currency area refers to the optimum geographic domain of a single currency or of several currencies, whose exchange rates are irrevocably pegged or will be unified (Mundell, 1961; Kenen, 1969). As a result the linked currencies can only fluctuate in unison against other currencies. Optimality can be considered to the extent that conditions within the area allow for adjustment to certain shocks and support for internal and external balance without the need for nominal exchange rate adjustment, and depending on whether capital is free to move, without the use of monetary policy. The benefits and costs associated with pegged currencies or monetary unions can be addressed by reference to this literature.

In choosing an approach to managing the exchange rate exchange rate policy makers face a fundamental constraint, the so-called macroeconomic policy "trilemma" (Taylor and Obstfeld, 2003; Taylor, 2004). It is not possible for governments to simultaneously conduct an independent monetary policy, have an open capital account and maintain a stable exchange rate. It is possible to choose only two out of these three options. If capital controls are in place, 
then a country can fix its exchange rate and run an independent monetary policy. This choice is not possible when capital flows are not restricted as inflows will tend to offset any monetary policy directed at domestic objectives.

By linking their currencies to the USD the members of the GCC, all of whom maintain open capital accounts, have each opted to forego an active monetary policy as part of the program of stabilization en route to a currency union. This means that one policy tool for responding to asymmetric domestic shocks which are specific to parts of the union has been lost (Karam, 2001) (Note 8). With a common currency this fact will be formalized for the members and should they then maintain a peg to the USD, then the group itself would not have the option of an independent monetary approach (Note 9). Shocks to the anchoring country, in this case the US, tend to be directly transmitted to the targeting country with interest rate changes in the former leading to a corresponding change in the latter (assuming no capital controls) (Note 10).

\section{Benefits and Costs of a Monetary Union}

The benefits of a currency union are identified as stemming from the beneficial impact on trade and investment due to exchange rate stability. Greater economic integration is a result. To the extent that intra-regional trade is stronger pre-establishment of the currency union, then greater benefits are likely (Bayoumi and Mauro, 2001). Currency fluctuations are considered to raise the risks and cost of international transactions and hence reduce the volume of trade (Nitsch, 2002). (Note 11) While empirical studies have tended to find little support for this assertion, there is growing evidence for the converse proposition that reducing exchange rate variability significantly increases trade (Rose, 2001, 2002, Barro and Tenreryo, 2007, Yetman, 2007). Scale economies are also likely in the area's foreign exchange market, reducing prices and volatility in respect of external relations with non-members. With increased liquidity for the regional currency, greater development and integration of capital markets will be facilitated. Where the group's monetary policy is driven by a dominant member, then a member can gain credibility from its alignment within the group.

There is also some evidence on likely distributional effects of a union on the trade of individual member states. While evidence from the EU supports the view that the European monetary union (EMU) has lead to increased intra-regional trade overall, for some members the effect has, in fact, been negative (Aristotelous, 2006, Miccos, Stein and Ordonez, 2003). Countries that are more open to trade are seen to benefit to the greatest extent. The more trade among members is in manufactures where price is set by firms rather than on world markets, then the union is likely to bring greater benefit as well (Note 12).

Currency union is also expected to promote policy coordination and increase price transparency in the region, further enhancing the stability of the business environment. This will lead to direct gains in terms of increased trade as well as assisting the unification of bond and equity markets and the general efficiency of financial services. There should be greater cross-border investment, economic diversification and greater fiscal discipline among member states. In the context of a common market, the GCC will also have a stronger unified voice in its external relationships.

Costs of a currency union tend to centre on the loss of the exchange rate as a tool of managing the economy and the lack of an independent monetary policy capability by members in the face of unexpected, asymmetric shocks to the area (Bayoumi and Mauro, 2001) (Note 13). Shocks that adversely impact some, but not all member states will likely not be handled by a single national monetary policy and so the potential costs are higher if effective policy options for adjustment are lacking. There is debate as to whether, in a currency area, production is likely to become more spatially concentrated, making the area's economy more susceptible to asymmetric shocks or rather, increased integration will lead to greater economic convergence (Tavlas, 1993, de Grauwe, 2005). Without suitable mechanisms for sharing risk and smoothing shocks, including fiscal transfers and integrated capital and credit markets, countries suffering from adverse shocks will have an incentive to leave the system (Yehoue, 2007). To the extent that other adjustment mechanisms are weak, the absence of monetary policy as a tool can not only hamper economic adjustments, but can also exacerbate the impact of an asymmetric shock on individual member states (de Grauwe, 2005). There will also be change-over costs in switching to a new currency and administrative costs due to formation of new institutions.

Often political factors will dominate the economic criteria in assessment of the desirability of currency areas. How smaller members will be affected and how a dominant member(s) uses its influence are important considerations. Historically most currency unions have formed in the context of a political union (Bayoumi and Mauro, 2001) (Note 14).

\section{The Likelihood of a Successful Monetary Union}

The literature deals with a number of criteria or pre-conditions which indicate the likelihood of any currency area or monetary union being successful (Tavlas, 1993, de Grauwe, 2005, Yehoue, 2005, 2007, Bayoumi and Mauro, 2001). Several broad areas can be identified: 
(1) The extent of economic integration and convergence.

(2) The degree of factor mobility and domestic price flexibility.

(3) The existence of a system of fiscal transfers to compensate for failings of factor markets in responding to shocks.

(4) The political will.

These address issues which impact the level of net benefits arising from the union and which are likely to influence the nature and extent of shocks to the union and the ability of economies to subsequently adjust to any shocks.

\subsection{Economic Integration and Convergence}

Smaller and more open economies are likely to be (relatively) favoured by joining a currency area since the exchange rate is less relevant as an adjustment tool (Bayoumi and Mauro, 2001). Moreover, the higher is the area's intra-regional trade and investment linkages, the greater the likely benefits as a result of the reduction in risk and transaction costs. As well, if prices are flexible and trade links are significant, shifts in trade flows can help in responding to asymmetric shocks, providing a reduction in the cost of adjustment (Krugman and Obstfeld, 2003).

The more similar are countries in terms of their production structure it is expected that shocks to the economies will tend to be symmetric as business cycles and longer term economic movements will be closely correlated (Mundell, 1961; Frankel and Rose, 1998) (Note 15).There is some evidence that a union may be self-fulfilling in that it may encourage increased economic and financial integration and similarity in economic structures, raising the likelihood of a greater preponderance of symmetrical shocks for the union (Mongelli, 2005; Jadresic, 2003, Yetman, 2007). However, it has been argued that increased integration post the union could lead to increased regional concentration and agglomeration of industries across economies (Tavlas, 19930). With evidence tending to provide mixed results, de Grauwe (2005) claims that it is in the end an empirical question. To the extent that there are such concentration effects, then sector specific shocks will tend to be country or region specific. For developed economies, at least, intra-regional trade is likely to be more intra-industry in nature, while services, which become relatively more important as economic development proceeds, tend to be less concentrated across an economy. Under such conditions, shocks would be expected to be more symmetrical(Note 16).

\subsection{Factor Mobility and Flexibility}

Intra-regional adjustment to changing conditions without diverging inflation and unemployment rates can be assisted in the short-term by price and wage flexibility (Karam, 2001). This will decrease the need for fiscal transfers and other adjustment measures (given that monetary policy and direct nominal exchange rate control is not available). Mobility of factors reduces the need for factor prices to adjust and will assist in adjustment to more permanent shocks providing a more long term adjustment mechanism (Mundell, 1961). Internal labour mobility will help alleviate unemployment in areas suffering adverse shocks and attenuate inflationary pressures in expanding areas (Creighton, 2006).

Evidence from Europe suggests that wages adjust relatively slowly to shocks for a variety of institutional rigidities in labour markets. There is also low price flexibility as a result of non-competitive tendencies and persisting government market programs. These rigidities raise the cost of monetary union (de Grauwe, 2005). Evidence from the US indicates that the high degree of inter-regional labour mobility acts to mitigate the impact of unemployment shocks, in contrast to the situation in the EU (Mongelli, 2005).

Similarly, FDI provides for a long term adjustment response and also involves full financial integration, including capital and credit markets (Sorensen and Yosha, 1998) (Note 17). Countries in a currency area can also share risk through cross-country asset-holding of residents (McKinnon, 2004). If residents hold claims to dividends, interest income etc from other countries, then this can help smooth adjustments in the short term. Within the Eurozone, FDI flows have risen and have been seen to be responsive longer term to changes in regional economic conditions (Mongelli, 2005). This is seen as increasing the risk-sharing among members ex post.

\subsection{Extent of Fiscal Transfers}

If governments within a union keep control of their own budgetary powers there is the problem that this could increase the likelihood of asymmetric disturbances. A centralized budget would alleviate this problem and allow for fiscal transfers in response to asymmetric disturbances to help maintain incomes across the area. However, this may not be easy to achieve politically. Fiscal integration which allows for fiscal transfers to alleviate uneven shocks can be important for smooth out the impacts (Kenen, 1969).

\subsection{Political Will}

Political factors often dominate the economic factors in successful establishment of monetary integration (Tavlas, 1993), Political commitment is also needed to overcome resistance to issues related to loss of sovereignty which is 
part of joining a monetary union (Fasano and Schaechter, 2003). Jadresic (2002) argues that a lesson from previous monetary unions indicates that a significant level of political integration is needed to ensure success. The role of a dominant state in the union can be important in this regard.

\section{GCC and the Criteria}

Based on the above discussion it is useful to look at the institutional and structural characteristics of the GCC member economies in order to assess the validity of any currency union. This raises a number of questions. To what extent are there favourable conditions in place? If, as is likely, only some criteria are met what does this imply, and to what extent may some of the conditions be established ex post? Are there other issues that need to be considered? While there is no simple check-list, an attempt is made to gauge how the GCC is positioned and what issues need to be addressed.

As evidenced from the EU experience, pre-union convergence was an important element in setting the stage for a successful union, along with a suitable institutional framework for executing agreed monetary policies and fiscal arrangements (Fasano and Schaechter, 2003). Adoption of suitable convergence criteria can foster consistency in sound budgetary stances and price stability across the group. In the GCC, a set of criteria have been agreed in principle by central banks along similar lines to those adopted for the Eurozone. They include the following:

(1) Inflation should be no more than 2 percentage points above the average GCC rate

(2) Public debt (external and local) should be no more than 60 per cent of GDP

(3) Short term interest rates should be no greater than 1.5 percentage points above the GCC average level (of the lowest 3 rates).

(4) Budget deficits should be less than 3 per cent of GDP, although flexibility is recognised because of the susceptibility of revenues and expenditures to the impact of oil price fluctuations; the figure is less than 5 per cent when oil prices are "weak".

(5) Reserves should equivalent to at least four months import cover.

The inflation target is aimed at avoiding the need for large changes in exchange rates when final parities are determined, encouraging stability in the interim arrangement in respect of rates pegged to the USD. Similarity of interest rates should also support more balanced current account flows within the currency area (Tavlas, 1993).

De Grauwe (2005) suggests that linking interest rates will lessen any significant disturbances in national capital markets on establishment of the union. The fiscal criteria seek to ensure that destabilising pressure to bail-out some member states is avoided and they prepare authorities for a cooperative and fiscally responsible policy framework after the union (Sturm and Siegfried, 2005). Countries pursuing widely different fiscal policies could create an undesirable conflict with the union's centralised monetary stance (Fasano and Schaechter, 2003). Negative spill-overs would result for other members. A growing fiscal deficit in one member state, for example, could undermine the zone's exchange rate stability and subject other members to diseconomies through raised interest rates and crowding-out of the private sector (Note 18). As well as economic strains, this would create political issues. Financial difficulties in one member could also affect the credibility of the union with the rest of the world, with wider implications for liquidity and interest rates (Jadresic, 2002). The more co-ordinated and sustainable is fiscal policy, the less cost to each member state from foregoing the use of an independent monetary policy. The level of reserves helps in the management of the exchange rate regimes and will give the GCC flexibility in any choice in respect of its eventual external exchange rate regime.

The following tables provide some evidence as to the progress to date. Interest rates are provided in table 5. Apart from inflation, the member states appear to be performing well on these convergence measures. As noted above, the high inflation in Qatar and the UAE (and to a degree Saudi Arabia) reflects exchange rate effects due to the falling USD and some structural problems in the domestic economy. Consequently it is not considered to be divergent policy settings driving the differences. This issue does highlight some difficulties at present, however, with several members looking to adjust their parity rates against the USD as a result of the current environment (Note 19). The low interest rate differentials reflect a high degree of monetary convergence due to the stable link the members have maintained with the USD and hence the co-movement with US interest rates.

Fiscal convergence is less evident in the GCC states (Tables 7-9). The difference in debt to GDP ratios is related to different approaches to budgetary policy over time and reflects varying oil income sources across states as well as the variability of oil prices and spending priorities. It should be noted, however, that it is often not clear what constitutes the public sector in GCC countries and how significant are undisclosed foreign assets (Sturm and Siegfried, 2005). It is difficult, therefore, to clearly assess the question of sustainability of public finances. Looking at the government fiscal position (inclusive of oil revenues) can be misleading (Table 7). Fiscal stances 
vary across members and are vulnerable to movements in oil revenues. Reference to non-oil budget balances relative to non-oil GDP is considered a preferred measure of a government's fiscal stance (Barrett and Ossowski, 2002). The figures in Table 8 indicate the dependence on oil revenues by GCC governments in order to maintain a sustainable fiscal position. Only the UAE and Kuwait appear to have adopted a more balanced fiscal stance in recent times. As suggested above, some member states, including Oman, face strong pressure to restructure their economies and have indicated that the fiscal criteria is too constraining, to the extent that they have indicated (along with Saudi Arabia) that the proposed date of 2010 is problematic for them (Note 20). The level of reserves (Table 5) currently meets the criteria of four months import cover (Hebous, 2006).

Further consideration of the longer-term sustainability of the union centres on the likely nature of shocks and the effectiveness of adjustment mechanisms. Econometric studies looking at the GCC have tended to focus on how linked are the economies of the member states. Abu-Bader and Abu-Qarn (2006) suggest that there are limited correlations in terms of long run economic relationships and short term business cycles. They also argue that asymmetric shocks will be in large part supply side driven and arise externally. Hebous (2006), on the other hand, indicates that business cycles tend to be highly correlated, while Darrat and Al-Shamsi (2005) find support for long run economic and financial ties connecting the six member states. To the extent that there is convergence of the economies, a supra-national monetary policy is more likely to be effective as there would be less asymmetric shocks.

However, notwithstanding the current position, efforts are under way to diversify and restructure economies with the push for privatisation, greater FDI inflows, attention to corporate governance and a widening and deepening of financial and capital markets (Hebous, 2006; Darrat and Al Shamsi, 2005). This suggests increased integration will result as economies become more complementary and less reliant on oil. (Note 21) Reduction of an existing array of non-tariff barriers and greater harmonisation of institutions, regulations and laws will further assist in this process (Dar and Presley, 2001). This could lead to increased regional concentration and agglomeration of industry with service industries not evenly dispersed across the region and increasing non-oil trade being in large part inter-industry in nature. While enhanced trade flows permit greater benefits arising from the monetary union, in this case it would mean that asymmetric shocks will become more likely and hence it would be increasingly important that effective adjustment mechanisms are in place.

Labour markets are relatively flexible because of the large share of expatriate labour whose numbers can be adjusted readily in response to demand shocks (Sturm and Siegfried, 2005). Cross-border mobility is also encouraged by cultural links, but requires that barriers restricting movement and recognition of qualifications are reduced (Karam, 2001). If more nationals move into the private sector, flexibility needs to be maintained, while harmonisation of labour market policies is also desirable. Increased investment in human capital would assist in development of an increasingly services based economy and address unemployment problems.

Integration of financial and capital markets is not well advanced in the GCC. This may, in fact, be encouraged by the union and hence allow further adjustment mechanisms to operate. (Note 22) Gains could arise from an expansion of these markets across the GCC due to a wider circulation of the single currency (Note 23). A very large and liquid capital market, with integration of bond and equity markets would give greater capitalization and trading; this would in turn serve to encourage savings and investment across the region.

The question of fiscal transfers is a political as much as an economic issue. To the extent that discretionary government transfers are feasible and well managed, then they can play a significant role in any adjustment process and ensure cohesion of the group.

The union will also enhance the collective bargaining position with major economies, including Europe, the US, China and Japan. The common currency could even provide an alternative vehicle for pricing oil and perhaps serve as an Islamic currency.

\section{Concerns}

A GCC consensus is needed in the areas of monetary, exchange rate and fiscal policies for the union, following its establishment. The management of currency reserves, establishing common monetary instruments and a decision as to the nature and location of any central monetary authority or central bank are all matters to be addressed. The nature of the new currency is also a matter of debate. Given that impediments continue to hamper economic integration, a major stumbling block to a successful monetary union remains the matter of political commitment (Darrat and Al Shamsi, 2005).

In the lead-up to 2010, there is already disagreement about some of the convergence criteria, including the matter of public debt caps and setting of interest rates. A framework is needed, therefore, for resolving differences on fiscal policies although the diversity withinin the GCC could make adoption of certain policies such as wealth transfers to 76 
poorer members, complete factor market integration and agreement on institutional arrangements, harder to achieve. Policy setting, along with monitoring and assessing the convergence criteria, will require improved transparency and national data systems in the member states (Sturm and Siegfried, 2005, Krueger and Kovarich, 2006).

The choice of exchange rate regime for the GCC with its trading partners will be critical. The current peg to a (falling) USD has already proved problematic for some members given existing trade patterns. However, the choice would seem to be between a currency pegged to either the USD or a basket of currencies, rather than between a fixed or floating rate (Hebous, 2006).

\section{Conclusion}

The member states of the GCC are planning to establish a monetary union in 2010. Currently there is some debate as to the likelihood of achieving this target date and whether all members are prepared to participate fully. An overview of the GCC economies suggests that while they exhibit a degree of similarity in terms of their economic structures, this is likely to change in the future as energy reserves in some states run-down and as a result of growing pressures to reform and diversify economies.

The literature identifies a number of potential gains that could flow to the member states from the introduction of a union; these centre around increased trade and integration of financial and capital markets across the group and a stronger position with its trading partners. The costs that can arise stem in large part from the loss of the exchange rate and active monetary policy as adjustment policy tools by member states.

The likelihood of the union being successful depends, therefore, on the nature of the economic shocks that are likely to occur following its establishment and to what extent alternative adjustment measures exist and might be effective. Flexibility and stability in the face of asymmetric shocks are key objectives. A number of pre-conditions or criteria are identified as important to maximise expected benefits. These include the extent of trade between members and the similarity in their economic structures, the degree of factor mobility and domestic price flexibility across the group and whether a system of fiscal transfers is feasible between members. While these do not provide a simple check-list against which the GCC can be measured or assessed, they provide a basis for observation and some assessment.

The GCC members have instituted a number of so-called convergence criteria in the lead-up to 2010, aimed at creating a sound fiscal position and price stability. These are basically on track, but have put strains on some members to meet the 2010 deadline. A review of the GCC economies suggests that as the economies diversify, there is greater chance of asymmetric shocks to the group and hence there is a need to ensure that adjustment mechanisms are available. Efforts are needed to encourage greater labour market flexibility across the GCC and to foster capital and financial market integration. Agreement must also be reached regarding some form of fiscal transfer mechanism to assist members adversely impacted by shocks.

A number of political issues also need to be addressed including how a supra-national monetary policy and reserves management will be handled, common monetary instruments and improved transparency in reporting of economic and financial data. The setting of the exchange rate for the common currency with trading partners is obviously a key issue and goes to the question of credibility and sustainability of the union. The key will be the political will of the member states to address institutional issues and forego some degree of sovereignty.

\section{References}

Abu-Bader, S., and Abu-Qarn, A., (2006). On the Optimality of a GCC Monetary Union: Structural VAR, Common Trends and Common Cycles Evidence. Discussion Paper, 06-11, Monaster Center for Economic Research, Ben-Gurion University of the Negev, Israel.

Arab Monetary Fund, (2007). [Online] Available: http://www.amf.org.ae (November, 2007)

Aristotelous, K., (2006). Are There Differences Across Countries Regarding the Effects of Currency Unions on trade? Evidence from EMU. Journal of Common Market Studies, 44, $17-27$.

Barnett, S., and Ossowski, R., (2002). Operational Aspects of Fiscal policy in Oil Producing Countries. IMF Working Paper, 177, International Monetary Fund, Washington.

Barro, R., and Tenreyro, S. (2007). Economic Effects of Currency Unions. Economic Enquiry, 45, 1-23.

Bayoumi, T., and Mauro, P., (2001). The Suitability of ASEAN for a Regional Currency Arrangement. World Economy, 24, 933-54

Creighton, A., ((2006). Labour Mobility and Trans-Tasman Currency Union. Australian Economic Papers, 45, 1, $38-56$ 
Dar, H., and Presley, J., (2001). The Gulf Co-operation Council: A Slow Path to Integration?. World Economy, 24, 1161-1178.

Darrat, A., and Al Shamsi, F., (2005). On the Path of Integration in the Gulf Region. Applied Economics, 37, 1055-1062.

De Grauwe, P., (2005). The Economics of Monetary Integration. (6 ${ }^{\text {th }}$ ed.). Oxford University Press.

Eichengreen, B., and Bayoumi, T., (1999). Is Asia an Optimum Currency Area? Can it Become One? Regional, Global and Historical Perspectives on Asian Monetary relations. in S. Collignon, J. Pisani-Ferry and Y.C. Park (Eds.), Exchange rate Policies in Emerging Asian Countries, Routledge.

Fasano, U. and Schaechter, A., (Eds.), (2003). Monetary Union Among Member Countries of the Gulf Cooperation Council. IMF Occasional Paper, 223, International Monetary Fund, Washington.

Fasano, U., and Iqbal, Z., (2002). Common Currency. Finance and Development, December, 39, 1-7.

Frankel, J., and Rose, A., (1998), The Endogeneity of the Optimum Currency Area Criteria. The Economic Journal, 108, 1009-1025.

Hebous, S., (2006). On the Monetary Union of the Gulf States. Kiel Advanced Studies Working Paper, 431, Kiel Institute for the World Economy.

International Monetary Fund, (2007). World Economic Outlook. [Online] Available: http://www.imf.org/external/pubs/ft/weo/2007/02/pdf/statapp.pdf, (December, 2007)

International Monetary Fund, (2007a). Regional Economic Outlook, [Online] Available: http://www.imf.org/external/pubs/cat/longres.cfm?sk=20327.0, (October, 2007)

Jadresic, E., (2002). On a Common Currency for the GCC Countries. IMF Policy Discussion Paper, 02/12, International Monetary Fund, Washington.

Karam P., D., (2001). Exchange Rate Policies in Arab Countries: Assessment and Recommendations. Arab Monetary Fund Economic Papers, December, Arab Monetary Fund, Abu Dhabi, UAE.

Kenen, P., (1969). The Theory of Optimum Currency Areas: An Eclectic View. in Mundell, R. and Swoboda, A. (Eds), Monetary Problems of the International Economy, University of Chicago Press.

Krueger, R. and Kovarich, E., (2006). Some Principles for Development of Statistics for a Gulf Cooperation Council Currency Union. IMF Working Paper, 06/141, International Monetary Fund, Washington.

Krugman, P. and Obstfeld, M., (2003). International Economics: Theory and Policy. Addison-Wesley.

McKinnon, R., (2004). Optimum Currency Area and Key Currencies: Mundell I versus Mundell II. Journal of Common Market Studies, 42, 689-715.

McKinnon, R., (1963). Optimum Currency Areas. American Economic Review, 53, 717-25.

Miccos a., Stein, E., and Ordonez, G., (2003). The Currency Union Effect on Trade: Early Evidence from the European Union. Economic Policy, 18, 315-56.

Mongelli, F., (2005). What is European Economic and Monetary Union Telling us About the Properties of Optimum Currency Areas?. Journal of Common Market Studies, 43, 607-35.

Mundell (1961). A Theory of Optimal Currency Areas. American Economic Review, 51, 657-65.

Nitsch, V., (2002). Honey, I Shrunk the Currency Union Effect on Trade. The World Economy, 25, 457-74.

Sturm, M., and Siegfried, N., (2005). Regional Monetary Integration in the Member States of the Gulf Cooperation Council. European Central Bank Occasional Paper Series, 31, June, European Central Bank.

Rose, A., (2002). Honey, the Currency Union Effect on Trade Has'nt Blown Up. The World Economy, 25, 475-79.

Rose, A., (2000). One Money, One Market: Estimating the Effects of Common Currencies on Trade. Economic Policy, 15, 7-33.

Rose A., and Stanley, T., (2004). A Meta-Analysis of the Effects of Common Currencies on International Trade. Journal of Economic Surveys, 19, 347-65.

Sorensen, B., E., and Yosha, O., (1998). International Risk Sharing and European Monetary Unification. Journal of International Economics, 45, 211-38.

Tavlas, G., (1993). The New Theory of Optimum Currency Areas. The World Economy, 16, 663-85.

Taylor A. (2004). Global Finance: Past and Present. Finance and Development, March, 41, 28-31. 
Taylor A. and Obstfeld M. (2004), Global Capital Markets; Integration Crisis and Growth. Cambridge University Press.

Woertz, E., (2007). Demography and Political Violence in the Middle East. Gulf Monitor, October, 1, 2007, 16-19, [Online] Available: http://www.grc.ae/data/contents/uploads/Gulf_Monitor_no_6_3450.pdf (December, 2007).

World Bank, (2006).World Development Report 2007. Washington.

Yehoue, E., B., (2007). The CFA Arrangements-More than Just an Aid Substitute?. IMF Working Paper, 07/19, International Monetary Fund, Washington.

Yetman, J., (2007). Currency Unions, Trade Flows and Capital Flows. Pacific Economic Review, 12, 189-204.

Table 1. Oil and Gas Activities as Share of Economic Activity 2004 (Per cent)

Source: Arab Monetary Fund (2007); Hebous, 2006

\begin{tabular}{|l|l|l|l|}
\hline & GDP & $\begin{array}{l}\text { Government } \\
\text { Revenues }\end{array}$ & Exports \\
\hline Bahrain & 23.3 & 72.6 & 76.5 \\
\hline UAE & 47.6 & 77.7 & 35.8 \\
\hline Kuwait & 43.8 & 91.4 & 92.8 \\
\hline Oman & 62.2 & 66.2 & 68.0 \\
\hline Qatar & 86.8 & 55.3 & 90.0 \\
\hline Saudi Arabia & 35.8 & 84.1 & 88.4 \\
\hline GCC & 69.9 & 74.6 & 75.0 \\
\hline
\end{tabular}

Table 2. Confirmed Oil and Gas Reserves (Per cent of world production)

\begin{tabular}{|l|l|l|}
\hline & Oil & Gas \\
\hline Bahrain & - & 0.1 \\
\hline UAE & 8.2 & 3.4 \\
\hline Kuwait & 8.3 & 0.9 \\
\hline Oman & 0.5 & 0.6 \\
\hline Qatar & 1.3 & 14.4 \\
\hline Saudi Arabia & 22.1 & 3.8 \\
\hline GCC & 40.4 & 23.2 \\
\hline Middle East & 64.0 & 40.0 \\
\hline Latin America & 10.0 & 4.0 \\
\hline E Europe & 8.0 & 32.0 \\
\hline Africa & 10.0 & 8.0 \\
\hline
\end{tabular}

Source: (Steinhilber, 2006; Shihab-Eldin, 2006, Fasano and Iqbal, 2002) 
Table 3. GDP Growth (Per cent per annum)

\begin{tabular}{|l|l|l|l|l|l|l|l|}
\hline & $1998-2002$ & 2002 & 2003 & 2004 & 2005 & 2006 & 2007 \\
\hline Bahrain & 4.8 & 5.2 & 7.2 & 5.4 & 6.9 & 7.1 & 6.3 \\
\hline UAE & 4.0 & 2.6 & 11.9 & 9.7 & 8.5 & 11.5 & 5.8 \\
\hline Kuwait & 2.5 & 5.1 & 13.4 & 6.2 & 8.5 & 11.5 & 5.8 \\
\hline Oman & 3.6 & 2.6 & 2.0 & 5.6 & 6.7 & 7.1 & 5.7 \\
\hline Qatar & 7.4 & 7.3 & 5.9 & 11.2 & 6.5 & 6.7 & 4.7 \\
\hline Saudi Arabia & 1.5 & 0.1 & 7.7 & 5.3 & 6.6 & 5.8 & 6.5 \\
\hline
\end{tabular}

Source: International Monetary Fund (2007)

Table 4. Population and Unemployment in the GCC

\begin{tabular}{|c|c|c|c|c|}
\hline & $\begin{array}{l}\text { Population mid-2005 } \\
\text { (Million) }\end{array}$ & $\begin{array}{l}\text { Population < } 15 \text { years } 2004 \\
\text { (Per cent) }\end{array}$ & $\begin{array}{l}\text { Population Growth } 2004 \\
\text { (Per cent per annum.) }\end{array}$ & $\begin{array}{l}\text { Unemployment } \\
2004 \\
\text { (Per cent) }\end{array}$ \\
\hline Bahrain & 0.73 & 28 & 2.6 & 17.5 \\
\hline UAE & 4.62 & 25 & & 3.0 \\
\hline Kuwait & 2.58 & 26 & 7.5 & 4.9 \\
\hline Oman & 2.43 & 33 & 2.0 & 17.5 \\
\hline Qatar & 0.76 & 25 & 7.5 & 3.0 \\
\hline Saudi Arabia & 24.57 & 37 & 2.3 & 15.0 \\
\hline GCC & 35.72 & 33. & 7.0 & n.a. \\
\hline
\end{tabular}

Source: World Bank (2006)

Table 5. (Economic Indicators 2005)

\begin{tabular}{|l|l|l|l|l|l|l|l|l|}
\hline & $\begin{array}{l}\text { Fiscal } \\
\text { Balance } \\
\text { (Per cent } \\
\text { of GDP) }\end{array}$ & $\begin{array}{l}\text { Government } \\
\text { Debt (Per cent } \\
\text { of GDP) }\end{array}$ & $\begin{array}{l}\text { Inflation } \\
\text { (Per cent } \\
\text { p.a.) }\end{array}$ & $\begin{array}{l}\text { Per } \\
\text { capita } \\
\text { GDP } \\
\text { (USD) }\end{array}$ & $\begin{array}{l}\text { Exports } \\
2003 \\
\text { (Per cent } \\
\text { of GDP) }\end{array}$ & $\begin{array}{l}\text { Current } \\
\text { Account } \\
\text { (Per cent } \\
\text { of GDP)* }\end{array}$ & $\begin{array}{l}\text { Short-run } \\
\text { interest } \\
\text { rates } \\
\text { (Per } \\
\text { p.a.) }\end{array}$ & $\begin{array}{l}\text { Official } \\
\text { Foreign } \\
\text { Exchange } \\
\text { Reserves } \\
\text { (USD B)** }\end{array}$ \\
\hline Bahrain & 1.4 & 30.3 & 2.6 & 15412 & 83.9 & 20.6 & 2.0 & 2.1 \\
\hline UAE & 27.4 & 9.6 & 8.0 & 22643 & 79.1 & 21.0 & 1.2 & 23.6 \\
\hline Kuwait & 46.9 & 13.1 & 3.9 & 23069 & 54.8 & 52.5 & 1.7 & 7.0 \\
\hline Oman & 14.5 & 10.8 & 3.2 & 11890 & 56.2 & 19.4 & 2.1 & 4.0 \\
\hline Qatar & 11.8 & 30.5 & 8.8 & 44500 & 72.0 & 49.1 & 2.4 & 3.3 \\
\hline $\begin{array}{l}\text { Saudi } \\
\text { Arabia }\end{array}$ & 18.4 & 39.0 & 0.7 & 10936 & 45.9 & 33.1 & 1.8 & 23.4 \\
\hline GCC & 24.0 & - & 4.5 & - & 55.8 & 36.2 & - & - \\
\hline
\end{tabular}

* 2006

** Underestimates reserves held in Ministries and investment agencies

Source: Arab Monetary Fund (2007) 
Table 6. Inflation (Per Cent per annum)

\begin{tabular}{|l|l|l|l|l|l|l|l|}
\hline & $1998-2002$ & 2002 & 2003 & 2004 & 2005 & 2006 & 2007 \\
\hline Bahrain & -0.8 & -0.5 & 1.7 & 2.3 & 2.6 & 2.6 & 3.0 \\
\hline UAE & 2.2 & 2.9 & 3.1 & 5.0 & 8.0 & 10.0 & 5.0 \\
\hline Kuwait & 1.5 & 0.8 & 1.0 & 1.3 & 3.9 & 3.5 & 3.0 \\
\hline Oman & -0.3 & -0.2 & 0.2 & 0.8 & 1.9 & 3.5 & 2.0 \\
\hline Qatar & 1.7 & 0.2 & 2.3 & 6.8 & 8.8 & 9.0 & 8.0 \\
\hline Saudi Arabia & -0.7 & 0.2 & 0.6 & 0.4 & 0.7 & 1.0 & 1.0 \\
\hline GCC & 0.2 & 0.8 & 1.2 & 1.8 & 2.9 & 3.2 & 2.4 \\
\hline
\end{tabular}

Source: International Monetary Fund (2007a).

Table 7. Central Government Fiscal Balance (Per cent of GDP)

\begin{tabular}{|l|l|l|l|l|l|l|l|}
\hline & $1998-2002$ & 2002 & 2003 & 2004 & 2005 & 2006 & 2007 \\
\hline Bahrain & -0.6 & -3.9 & -2.0 & 0.3 & 1.4 & 4.2 & 0.7 \\
\hline UAE & 1.6 & 10.5 & 13.8 & 19.5 & 27.4 & 30.2 & 31.4 \\
\hline Kuwait & 20.5 & 19.3 & 18.0 & 23.6 & 46.9 & 58.0 & 62.5 \\
\hline Oman & 3.9 & 5.6 & 5.8 & 8.5 & 14.5 & 18.1 & 17.6 \\
\hline Qatar & 0.8 & 8.4 & 4.3 & 18.9 & 11.8 & 18.1 & 19.7 \\
\hline Saudi Arabia & -4.3 & -5.9 & 1.2 & 9.6 & 18.4 & 18.5 & 20.3 \\
\hline
\end{tabular}

Source: International Monetary Fund (2007)

Table 8. Central Government Non-Oil Fiscal Balance (Per cent of Non-Oil GDP)

\begin{tabular}{|l|l|l|l|l|l|l|l|}
\hline & $1998-2002$ & 2002 & 2003 & 2004 & 2005 & 2006 & 2007 \\
\hline Bahrain & -25.4 & -33.9 & -33.1 & -29.3 & -29.8 & -30.3 & -29.0 \\
\hline UAE & -32.0 & -30.7 & -28.0 & 21.3 & -17.3 & -14.9 & -12.1 \\
\hline Kuwait & -39.8 & -44.9 & -47.5 & -48.7 & -39.4 & -31.9 & -28.3 \\
\hline Oman & -52.1 & -55.8 & -56.1 & -64.9 & -66.5 & -69.5 & -70.4 \\
\hline Qatar & -50.4 & -42.1 & -47.0 & -42.6 & -61.3 & -56.5 & -50.9 \\
\hline Saudi Arabia & -41.9 & -46.9 & -46.7 & -46.5 & -52.3 & -55.2 & -54.8 \\
\hline
\end{tabular}

Source: International Monetary Fund (2007)

Table 9. Government Debt (Per cent of GDP)

\begin{tabular}{|l|l|l|l|l|l|l|l|}
\hline & $1998-2002$ & 2002 & 2003 & 2004 & 2005 & 2006 & 2007 \\
\hline Bahrain & 29.0 & 32.2 & 37.1 & 35.1 & 30.3 & 26.0 & 23.5 \\
\hline UAE & 5.5 & 5.3 & 6.7 & 8.4 & 9.6 & 9.0 & 7.3 \\
\hline Kuwait & 40.0 & 30.0 & 23.8 & 18.5 & 13.1 & 10.0 & 9.0 \\
\hline Oman & 27.4 & 17.4 & 16.4 & 15.5 & 10.8 & 8.4 & 7.4 \\
\hline Qatar & 59.9 & 47.1 & 41.5 & 34.0 & 30.5 & 23.1 & 20.3 \\
\hline Saudi Arabia & 96.7 & 96.9 & 82.0 & 65.0 & 39.0 & 15.2 & 7.1 \\
\hline
\end{tabular}

Source: International Monetary Fund (2007)

\section{Notes}

Note 1. A renewed interest in currency or monetary unions has been driven in large part by the experience of the European Monetary Union (EMU), "dollarisation" experience in Latin America and recent financial crises in East 
Asia and elsewhere.

Note 2. Members, under different arrangements, had to various degrees been effectively fixed to the USD for some time prior to this (Fasano and Iqbal, 2002). Europe had similar experiences with some countries linking to the Deutschemark ahead of the establishment of the EMU.

Note 3. Saudi has 70 per cent of total GCC population and accounts for more than half of the group's output. The next largest, the UAE, about 12 per cent of the population and about 20 per cent of the group's output.

Note 4. The average trade to GDP ratio is around 88 per cent with the trade balance having risen sharply over the past 5 years.

Note 5. Reserves also are currently being depleted much more slowly in the GCC than in other areas. The area's share of global oil and gas output is 22 per cent and 6.5 per cent respectively.

Note 6. Differences in per capita income levels are not as great, in fact, as those experienced in the EU.

Note 7. Although Oman has already opted out of the current timetable for domestic economic reasons, other member states are continuing to support the 2010 union, albeit with varying enthusiasm. Kuwait has moved its peg away from the US dollar to a basket of currencies. Other member states have been considering a similar response to the falling dollar or alternatively, revaluation of their dollar pegs. Any policy adjustments in light of changing external situations need not necessarily undermine the basic motivation for a currency union, nor necessarily of themselves hinder the process.

Note 8. Interest rate changes within the union can not be targeted at individual member states, irrespective of growth and unemployment conditions there.

Note 9. The question of what the exchange rate policy should be in respect of the common currency is not the focus of this paper; some observations are made, however.

Note 10 . To the extent that monetary and policy making institutions are weak or under-developed then fixing to a more "credible" currency can be beneficial. Similarly, within a union, weaker states are locked-in to the monetary discipline (or not) of the central authority.

Note 11. There is debate as to the impact of exchange rate volatility on trade, both from a theoretical and empirical perspective (de Grauwe, 2005, Rose, 2000).

Note 12. Exchange rate fluctuations have a more pronounced affect on the price of differentiated products than on homogeneous commodities which typically have a world price (Bayoumi and Mauro, 2001).

Note 13. Shocks could represent a host of factors. Oil price rises, for example, would be seen as symmetric to the extent that all members were significant oil exporters. Sectoral shocks would be more likely asymmetric if different countries or regions within the union were more specialized; shocks could be specific, for example, to the tourist sector, property market, manufacturing or finance markets and the regional impact could be quite varied.

Note 14. Examples include the CFA franc zone and the rand zone in southern Africa. By way of contrast, the EU is a union of countries which traditionally have been strongly independent politically and in terms of internal economic management (Bayoumi and Mauro, 2001). Any system needs to consider the particular needs of the group. To that extent, the EU or other experiences are a guide only.

Note 15. Economies that are themselves more diversified in terms of their production mix will be better able to deal with shocks to the economy and would better be able to adjust to sector specific shocks (Kenen, 1969).

Note 16. Evidence from the EU indicates that such concentration effects are not evident. However, that reflects the significant level of intra-industry trade in differentiated manufacturing products and the dominance of service industries (de Grauwe, 2005)

Note 17. Cross-ownership of assets and cross-border savings and credit flows will help share risk through smoothing of consumption over time and across members (Yehoue, 2007).

Note 18. The issue of moral hazard exists, with incentives existing for members to pursue independent deficit strategies in anticipation of being bailed-out by the union.

Note 19. The recent sharp decline in the value of the USD against major currencies has been a cause of concern for members. A meeting of the governors of the central banks of GCC members in December 2007 agreed to maintain existing currency pegs to the USD in an effort to keep the proposed monetary union on track. It is likely, however, that revaluation within this arrangement for some or all members will be likely in the future, perhaps with a shift by some to a peg against a basket of currencies, reflecting a desire for a monetary policy independent of that in the US. 
Note 20. In particular the limit of 3 per cent of GDP for public debt is seen as a restraint on the economy in Oman as it seeks to diversify in the face of declining oil revenue and high unemployment. Kuwait, meanwhile, has disagreed with the common inflation targets.

Note 21. After establishment of a monetary union, increased efficiency in financial services and general resource allocation, improved transparency in prices and more coordination in investment activities will all create a more favorable environment for integration to expand (Fasano-Filho and Schaechter, 2003).

Note 22. Restrictions still exist on foreign ownership of equity and real estate, hindering establishment of cross-border commercial presence and permitting limited cross-listing of stocks; there is little cooperation across exchanges.

Note 23. In the EU financial market integration has risen since the formation of the monetary union. This provides a degree of private risk-sharing. 